\section{DE DE GRUYTER OPEN}

Przedsiębiorczość i Zarządzanie Entrepreneurship and Management University od Social Sciences Publishing House ISSN 1733-2486

Volume XVI, Issue 1, pp. 173-180 DOI 10.1515/eam-2015-0011

Łukasz Sułkowski

University of Social Sciences

\title{
Management - Forecasting the Future Cognitive Challenges in Management Science 3
}

\begin{abstract}
This paper is the third publication from the series of three articles about cognitive challenges in management science. It is the result of the further discussions and reflections concerning the cognitive problems of management after publication of the books about epistemology of management. The paper is a trial to forecast the main cognitive trends and tendencies on the basis of the diagnosis made in two papers in series "Cognitive challenges in management science". The chosen trends in development of management sciences are: expansion of natural sciences, growing inter-disciplinarity of research, growing specialization, net-marketing in management discourse, challenge of cultural relativism, growing criticism and reflexivity. Response of management sciences to the challenges connected to: interdisciplinary nature, growing specialization, and expansion of natural history can lead to further development of our discipline, but the possibility of disintegration also should not be ruled out. Deepening specialization, lack of long-range theory, and growing significance of natural history could lead to disintegration of our discipline, whose fields would be incorporated by other domains. I think that in order to avoid this possibility it would be desirable to uphold the cohesion of management sciences through deepening the cognitive reflection and openness to inspirations originating in other areas of science. But future is difficult to predict and maybe other trends that are not too visible now will change management sciences in future.
\end{abstract}

Key words: management epistemology, management methodology, management paradigms. 


\section{Introduction}

The epistemological and methodological problems in management are very complex for theoretical reflection. Cognitive value of such analyses could be linked with growing methodological awareness and reflectivity of our scientific community. These are creative cognitive processes, which do not base solely of developing knowledge, but means also critical and alternative thinking. The presented reflections do not represent a single, the only or even dominant way of experiencing changes in contemporary management sciences discourse. It is more search for a wider perspective going to the identification of the "macro-trends" in management and organization research. The important statement is inclusion of interdisciplinary and pluralist ways of thinking existing in many social disciplines to management itself. It will still constitute "theory jungle" although we have earned theoretical, practical, and institutional achievements.

Management sciences is an unbalanced discourse, because they attach great importance to detailed applications and techniques, often neglecting at the same time epistemological and methodological foundations. There is an enormous number of works on management methodology, while questions concerned with the identity of researcher, paradigm, or preferred methodology are asked rarely. This state of affairs probably results from practical orientation of the scientific discipline, which from its onset "has its feet firmly on the ground "and avoids having its theoretical "head in the clouds". At the present stage our science can be characterized by a very complex internal structure of discourse, which necessitates theoretical consideration, because even the researchers themselves get lost in the tangle of theories [Introduction to: Sułkowski 2013].

The paper is a trial to forecast the main cognitive trends and tendencies on the basis of the diagnosis made in two papers in series "Cognitive challenges in management science".

The chosen trends in development of management sciences are:

1. Expansion of natural sciences;

2. Growing inter-disciplinarity of research;

3. Growing specialisation;

4. Net-marketing in management discourse;

5. Challenge of cultural relativism;

6. Growing criticism and reflexivity. 


\section{Natural sciences expansion}

In my opinion in the future we would experience expansion of natural sciences into the disciplines that were limited to social and humanities sciences [Behling 1980, pp. 483-490]. The examples taken from neuroscience, behavioral economy or evolutionary psychology prove that experimental method is useful in solving social problems. Computer simulations, biological anthropology or primatology researches are being used in research in many different fields: psychology, sociology, cultural anthropology, linguistics and management science as well. Management and organization similarly to other social sciences are stronger and stronger influenced by problems and methods of natural sciences [Whitley 2000]. We can mention here researches that are related to: making decisions, social communication, power execution, leadership, organization cultures which are present in neoevolutionary trend. Management sciences have to take this responsibility and follow new research results that describe human nature and the nature of social as well as organization bonds [Sułkowski 2012a, pp. 345-346].

\section{Evolutionary attitude}

An important cognitive perspective for the discipline of management and the theory of an organisation is neoevolutionism, due to its creative aspects that are adopted by the theory and practice of management, and also association with other scientific disciplines and methodology of research. This article depicts the ways to place neoevolutionary thinking in management. Motivation, people management and leadership are key figures for human resources management, they are strongly appealing to human nature and social group's nature. The effects of research results of evolutionary psychology and behavioural economics lead to new theories of leadership and motivation. Organisational behaviour was until now a discipline introducing the research results of other social sciences to management, not related to the neoevolutionary approach. Strategic management is connected with other factors that have an impact on strategic decision of managers which are the parts of evolutionary models - for instance, organizational culture might be treated as application of the group ties created as a consequence of evolution.

Management sciences are also capable of using the research results and methodology belonging to other disciplines related to neoevolutionary paradigm. Results worth presenting come from working with controlled methods, such as observations and social experiments, not often practiced in management. Results of the research provided by neuroscience, cognitive science, 
paleo-anthropology and primatology might be valuable for both sides of management science: not only theory, but also practice. Up to now, the most essential results are derived from behavioural economics and also finances, with a greater identification with economics than management [Sułkowski 2012b].

The roots of an evolutionary approach are naturalistic foundations and that is why it highlights the increasing role of modified functionalist-neoevolutionary approach [Sułkowski 2004].

\section{Growing significance of research inter-disciplinarity}

Multi-paradigmatic nature of management sciences leads to the inter-disciplinarity of research [Burrell, Morgan 1979]. Such nature is common to management practice and organization research [Guba, Lincoln 1994, pp. 105-117]. The scope of the inter-disciplinarity ranges from social and humanistic sciences like: economy, sociology, law, cultural anthropology, psychology, history, to formal and natural sciences like: mathematics, biology and physics [Pettigrew, Woodman, Cameron 2001, pp. 697-713]. Forecasting view allow to discover many courses visible in the development of management sciences, and which in historic view form the development of the discipline. Last few decades bring us into a conclusion that the interdisciplinary nature of management sciences would be of a greater meaning. The management in the inter-disciplinary tendency is not the exception [Brewer 1999, pp. 327-337]. In the effect, boundaries between disciplines and fields would slowly disappear, which confronts us with a challenge for exact science and academic community [Massey, Alpass, Flett et al 2006].

\section{Growing specialization}

From the perspective of the growing inter-disciplinarity of organization and management research, it seems to be paradoxical that the specialization is deepening. But the reason is quite simple, growing number of research results and several new emerging scientific fields are on the stage of building its identity. The main concentration area is not management and organization as a whole, but rather quite narrow field of research that is growing and has more inter-disciplinary character. The very good example of this tendency could be the development of the field of family businesses, that is booming the last 20 years and at the same time more and more interdisciplinary [Dyer, Sánchez 1998, pp. 287-295, Chrisman, Chua, Sharma 2003, pp. 1-63].

The increasing research results number, the deeper level of research and more professional character of the education end in greater specialization, 
which describe scientific discipline and subdisciplines as well. This tendency allows a deeper view into cognitive problems and methods chosen for the selected problem or question. However, it does not help to recognize research results that might be provided by other disciplines and that would be also able to form a basic theory explaining examined issue.

The integrity of management science is possible due to interdisciplinary nature of our science. Deeper specialization does not change it, providing that we are still ready to consider research results from other sciences. The management representatives are able to develop and enhance the identity of their chosen discipline but that does not mean profession-centrism or isolation from different disciplines.

\section{Net-marketing in management}

Scientific marketing in management is getting more and more important and has been developing in a dynamic way for the last few decades. This is connected with an expanding role of consulting, science popularization, management guru and management practice when research is considered. It has many advantages because it means introducing theory results into practice and the pragmatic mission of management sciences is fulfilled. But the disadvantage is that could end in making the research results simplified and the development not independent from passing trends. Moreover, some concepts which are „perceptually formatted” (meaning they are simple, not difficult to remember and lead to stereotypes), are not always more cognitively most adequate [Micklethwait, Wooldridge 1996]. The simplistic presentation of concept could be the source of the serious limitations of the management theory [Ghoshal 2005, pp. 75-91].

\section{Cultural relativism}

In my opinion it is impossible to avoid cultural relativity of management in some subdisciplines but it may not be done with a postmodernist form [Usunier 2000]. There is a chance individual cultural studies would no longer be of a high significance, and intercultural comparative analyses would become valuable. To me, cultural relativity is a globalization consequence, management concepts and methods diverge locally in connection with cultural context. Management sciences confronts ethnocentrism and this process, as well as cultural and economic globalization, is associated with cultural diversity threads in the management sciences discourse, for instance models of Hindu, Latin-American, Chinese and other organizations [Watson 2001]. The grooving interest in the area of cultural relativism, could be also observed in 
several new areas like; public management, marketing, communication studies and other [Blunt 1995, pp. 1-9].

\section{Increasing reflexivity and criticism}

The next tendency is growing axiological pressure that concerns management sciences. The future may put an emphasis on two aspects of organizing: ethnic and social. We can observe signs of this even today. Critical trend in management can be easily noticed and is oriented on justice and equality in somehow idealistic manner [Chouliaraki, Fairclough 2010, pp. 1213-1218]. The most essential issues include: business social responsibility [Banerjee 2008, pp. 51-79], employees subjectivity [Fleming, Spicer 2003, pp. 157-179], critical education [Grey 2004, pp. 178-186], ethos organization and characteristics of ethical organization [Fenwick 2005, pp. 31-48], critics of managerialism [Saravanamuthu, Filling 2004, pp. 437-452].

\section{Conclusion}

The fundamental questions of the development of management as a science in future are pushing the discipline for the widening its field, blurring the boundaries and deepening the specialization. Part of this tendencies like growing the scope of researched problems or showing auto-criticism are illustrating that management and organization is still very dynamic science that has large social influence.

The challenges for management sciences, such as: growing specialization, interdisciplinary nature and development of natural history would be followed by further development of management but brings to light a possibility of disintegration. That can be caused also by growing specialization, main role of natural history or lack of progressive theory, and some management fields may be taken in by other domains. My way to fight this threat would be maintaining the coherence of management sciences by broadening the cognitive reflection and tolerance for ideas from other sciences. Besides, these are only predictions, there is also a possibility that in the future other new tendencies would shape the management, ones that are not obvious nowadays ${ }^{1}$.

1 The deeper analysis of the problem in: Ł. Sułkowski, Epistemology of Management, Peter Lang International, Frankfurt-Berlin-Bern-Vien-Oxford-New York-London-Warsaw, 2013. 


\section{Bibliography}

Banerjee S.B. (2008), Corporate social responsibility: The good, the bad and the ugly, "Critical Sociology", 34.1, pp. 51-79.

Behling O. (1980), The case for the natural science model for research in organizational behavior and organization theory, "Academy of Management Review", 5.4, pp. 483-490.

Blunt P. (1995), Cultural relativism, 'good'governance and sustainable human development, "Public Administration and Development", 15.1, pp. 1-9.

Brewer G.D., The challenges of interdisciplinarity, "Policy Sciences", 32.4, pp. 327337.

Burrell G., Morgan G. (1979), Sociological Paradigms and Organisational Analysis, Heinemann, London.

Chouliaraki L., Fairclough N., Critical discourse analysis in organizational studies: Towards an integrationist methodology, "Journal of Management Studies", 47.6, pp. 1213-1218.

Chrisman J.J., Chua J.H., Sharma P. (2003), Current trends and future directions in family business management studies: Toward a theory of the family firm, "Coleman white paper series", 4, pp. 1-63.

Dyer G., Sánchez M. (1998), Current State of Family Business Theory and Practice as Reflected in Family Business Review 1988-1997, "Family Business Review", 11.4, pp. 287-295.

Fenwick T. (2005), Ethical dilemmas of critical management education within classrooms and beyond, "Management Learning", 36.1, pp. 31-48.

Fleming P., Spicer A., Working at a cynical distance: Implications for power, subjectivity and resistance, "Organization", 10.1, pp. 157-179.

Ghoshal S. (2005), Bad management theories are destroying good management practices, "Academy of Management Learning \& Education", 4.1, 2005, pp. 75-91.

Grey C. (2004), Reinventing business schools: The contribution of critical management education, "Academy of Management Learning \& Education", 3.2, pp. 178186.

Guba E.C., Lincoln Y.S. (1994), Competing Paradigms in Qualitative Research, in: N.K. Denzin, Y.S. Lincoln (ed.) Handbook of Qualitative Research, Thousand Oaks, CA: Sage, pp. 105-117.

Massey C., Alpass F., Flett R., Lewis K., Morriss S., Sligo F. (2006), Crossing fields: the case of a multi-disciplinary research team, "Qualitative Research", vol. 6(2).

Micklethwait J., Wooldridge A. (1996), The Witch Doctors. Making Sense of the Management Gurus, Times Books - Random House, New York. 
Pettigrew A.M., Woodman R.W., Cameron K.S. (2001), Studying organizational change and development: Challenges for future research, "Academy of Management Journal", 44.4, pp. 697-713.

Saravanamuthu K., Filling S. (2004), A critical response to managerialism in the Academy, "Critical Perspectives on Accounting", 15.4, pp. 437-452.

Sułkowski Ł. (2013, Epistemology of Management, Peter Lang International, Frankfurt-Berlin-Bern-Vien-Oxford-New York-London-Warsaw.

Sułkowski Ł. (2012a), Epistemologia i metodologia zarządzania, PWE, Warszawa, pp. 345-346.

Sułkowski Ł. (2012b), Neodarwinism in Organization and Management, Peter Lang International, Frankfurt-Berlin-Bern-Vien-Oxford-New York-London-Warsaw.

Sułkowski Ł. (2004), Neopozytywistyczna mitologia w nauce o zarządzaniu, „Organizacja i kierowanie", nr 1 (115).

Usunier J.C. (2000), Marketing Across Cultures, Pearson Education Limited, Third edition, Edinburgh Gate.

Watson T.J. (2001), In Search of Management: Culture, Chaos and Control in Managerial Work, Cengage Learning EMEA.

Whitley R. (2000), The intellectual and social organization of the sciences, Oxford University Press. 